\title{
Beyond Figures and Numbers Participatory Budgeting as a Leverage for Citizen Identity and Attachment to Place
}

\author{
Justyna Anders-Morawska \\ (iD) https://orcid.org/0000-0001-8913-5726 \\ University of Lodz \\ Faculty of International and Political Studies \\ e-mail: justyna.anders@uni.lodz.pl \\ Marta Hereźniak \\ (iD) https://orcid.org/0000-0002-7558-2688 \\ University of Lodz \\ Faculty of International and Political Studies \\ e-mail: martaherezniak@uni.lodz.pl
}

\section{Abstract}

The purpose of the paper is to examine the potential of participatory budgeting (PB) for the formation of citizen identity and attachment to the place in terms of individual, territorial and thematic focus. In the theoretical discussion, the authors analyse the concepts of place attachment, social identity and their influence on civic participation. The authors propose a conceptual framework for the analysis of relationships between PB, place attachment, and social identity. In the case of the community development model of PB, place attachment should lead to the citizens' increased inclination to participate. In the case of participatory democracy model of PB citizen participation can lead to a stronger place attachment. The conceptual framework presented in the paper requires empirical confirmation. Further research on the subject should revolve around the influence of place 
attachment on the formation of social identity and vice versa by application of the discussed models of PB. The placemakers should take into account literature-based evidence that advisory models of PB do not reinforce place identity. The places that apply one of the transition models should consider the evolution of their PB policies towards either community development model or participatory democracy model. By review of diverse theoretical approaches on place identity and local participation, the paper creates a solid foundation for further analysis of the relationships between the application of PB and the development of civic identity and place attachment.

Keywords: participatory budget, place attachment, social identity, community development, participatory democracy, place management

\section{Introduction}

This paper examines the potential of participatory budgeting $(\mathrm{PB})$ for the formation of civic (social) identity and attachment to the place of residence. As an instrument of participation, $\mathrm{PB}$ is nearly 30 years old. The success of the first PB process in Porto Alegre (Brazil) has been widely discussed in the literature (Wampler; Fuhr and Campbell; Baiocchi Participation; Baiocchi Militants and Citizens; Marquetti et al.; De Sousa Santos). Silva reports that after one decade since the launch of the process, ca. 20,000 citizens of the city took part in popular assemblies to decide upon the distribution of the local resources. The exemplary impact of Porto Alegre lies in a realised potential for involvement of those social strata that usually do not participate in political processes. According to the results of the Harvard University study, in 2002, 30\% of the regional assembles participants recruited from the lowest $20^{\text {th }}$ percentile of the entitled population (Harvard University Centre).

The nature of relationships between public authorities and citizens has been evolving towards residents' empowerment and community governance in which case the focal question is not whether to encourage social involvement and participation but rather how to organise it in the most effective manner. Inclusion is embedded in the notion of democracy per se; thus, the new instruments of participation are designed to address the issue of democracy deficit in public governance with special attention given to underprivileged social groups. Participatory budgeting is considered one of the most advanced tools of social inclusion. According to Wampler, PB should guarantee incorporation of citizen voice, assuring citizen vote (impact on decision-making processes on resource allocation), social justice via the inclusion of disadvantaged strata of the local 
community, and oversight of the PB process through accountability and transparency mechanisms.

In the theoretical discussion section, the authors analyse the concepts of place attachment, social identity and their influence on civic participation. It is proposed that participatory democracy model of $\mathrm{PB}$ described by Sintomer et al. is an instrument that allows the participation of non-elected citizens in the conception and/or allocation of scarce resources within local public finances, and therefore it enables to the greatest extent the formation of social identity that has both territorial and thematic focus (Stortone). Public participation can be understood as a process of social exchange and social cooperation (Simmons and Birchall). Hence, the application of the notions of social and place identity can be useful for the understanding of the residents' willingness to participate in place-related initiatives. There is evidence (Scannell and Gifford) that people are more attached to places that facilitate social relationships and group identity. In this context, the advanced models of $\mathrm{PB}$ can be seen as a means to stimulate grassroots initiatives and foster community integration, and as a result, to create and reinforce place attachment.

\section{Examining the relationship between place attachment, social identity and participation}

Places thrive and evolve largely due to the multiplicity of relationships and interactions among its residents. These relationships lead to communal experiences of a place shared by its citizens (Campelo) and eventually to the production of a bond between the two. The nature of this bond has been a subject of research for scholars of diverse academic backgrounds, only to mention sociology, human geography, environmental psychology, anthropology and other (Cross). Central to the discussion on how this bond is created are the notions of place attachment, with corresponding concepts of the sense of place (Relph) and place identity (Hafer and Ran).

Conceptualisations of place attachment and sense of place (also spirit of a place, Genius Loci, atmosphere of the place, Topophilia) have been equivocal, with some authors putting the mark of equation between them and applying them interchangeably (Low) while others theorising sense of place as a broader term which harbours place attachment, place identity and place dependence (Jorgensen and Stedman). In yet another understanding, place identity, place dependence and the sense of place are all variations of place attachment (Manzo). According to Campelo, sense of place and place attachment are closely related "because a sense of place implies sensory, emotional, cognitive and subjective experiences that lead 
to a positive emotional bond (attachment) with a place, the feeling of pride and wellbeing" (Braun et al.).

Scannell and Gifford propose a tri-component model with person, process and place dimensions as foundations of place attachment. The person dimension suggests that attachment occurs on both: individual (personal connection to a place) and group level (sharing a symbolic meaning of a place among members). Within the process dimension, place attachment is a psychological process consisting of three aspects: affect (authentic emotional bond), cognition (memories, beliefs, meaning and knowledge of a place) and behaviour (proximity-maintaining, reconstruction of a place). Ultimately, the place dimension of attachment has two aspects: social (social ties, belongigness to the neighbourhood, familiarity with fellow residents) and physical (spatial).

Place attachment performs important functions. It equips residents with the sense of security, assists in goal achievement (people become more attached to places that endorse the accomplishment of their goals), provides continuity (stable sense of self), gives a sense of belongingness, enhances identity and gives rise to self-esteem (Scannell and Gifford).

As it was previously noted, the concept of place attachment defines how people connect to various places. In terms of practical applications, it is thus valuable to examine the effect of such bonds on identity development, place-making and place management (Altman and Law) or how place attachment can be applied to plan and encourage the use of public space. Hence, in the discussion on place attachment, the concept of place identity should also be included. Kerr and Oliver argue that place identity is social, pluralistic, fluid and co-produced. Kavaratzis and Hatch posit that it is the product of the meaning-making process between residents and the place, with the former being both producers and consumers of identity.

These findings implicate that place identity is created via citizen participation in the reality of the place. Following the social character of place identity, it is also worth mentioning the approach proposed by Hafer and Ran who argue that citizen participation has yet another function. Namely, it leads to the construction of citizen identity as social identity, which further impacts citizen motivation to participate. In the classic definition, Tajfel describes social identity as "the individual's knowledge that he belongs to certain social groups together with some emotional and value significance to him of his group membership" (292). Furthermore, Proshansky et al. argue that place identity becomes a part of an individual's self-identity and "consists of knowledge and feelings developed through everyday experiences of physical spaces" (Gieseking 73) (see fig. 1). 


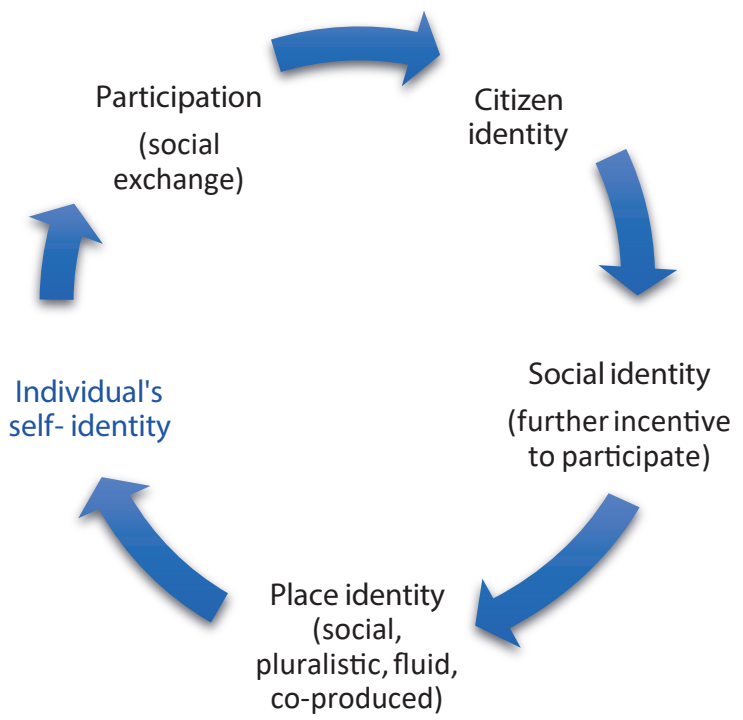

Figure 1. Participation - identity loop.

As public participation may be defined as a process of social exchange involving social groups (Roberts), the notions of social identity and place identity become valuable also for understanding the residents' inclination and motivation to participate in the co-creation of a place (Lowneds et al.). For instance, some researchers suggest that social identity drives the way people relate to the place and how they behave in it individually (Ashforth et al.) and collectively (Hague), mainly because citizens feel that they are a part of a larger civic identity built around the place (Lowndes et al.). Moreover, Scannell and Gifford observe that people are attached to the places that facilitate social relationships and group identity - which holds multiple implications for the way places are managed. It is also proposed that "participation that citizens view as authentic (e.g., direct, ongoing, and affording the opportunity to make substantive contributions to various stages of the policy process) will most likely be an influential setting for the construction of social identity" (Hafer and Ran 214).

\section{Participatory budgeting: from participation by invitation to community governance}

The transformation of relations between citizens and public administration has been widely discussed in the literature (i.e. Fung; Maton; Peters and Pierre). In many countries, the dominant discourse on these relations revolves around the changing 
roles of citizens from passive subjects of decision-making processes, through voters, customers, partners towards the key stakeholders (Vigoda). In the citizen-driven model of public policy, empowerment is a key component of participation (Ingram and Smith).

Empowerment in this context means letting citizens play an important role at all stages of policy processes: analysis, formulation, implementation and evaluation. The shift from customer-centred approach (responsiveness) to collaboration is at the core of the changing dynamics of the administration-citizen relationship. There are many methods of citizens' involvement in the processes of local policymaking that might be referred to as participation by invitation, such as citizens juries, deliberative panels or planning cells and their local variants, to name just a few. Local authorities are responsible for putting these methods in motion by inviting citizens to have a say about local affairs, which makes participation a topdown process. As it is proposed by Allegretti, "arenas of participation by invitation are the ones created when one or more institutions officially opens social dialogue spaces and admits the presence of citizens in moments of public debate and decision-making" (48).

Participatory budgeting makes an important difference when compared with other instruments of participation by placing a citizen in the centre of the process of microallocation of local finances and by providing an opportunity to experience tangible results of involvement from an individual perspective (Stortone; Avritzer). Santos posits that the PB is a means to "democratize democracy". As a personal re-evaluation of gains and cost of involvement continues, taking part in a social exchange that revolves around the $\mathrm{PB}$ (analysing personal and group needs and wants, formulating proposals, deliberation, voting, observing implementation and grasping results) contributes to the formulation of multidimensional individual identity. The multi-layered construct of identity that emerges in the process of deliberation of the PB entails: active citizen identity (of self being the one who participates), territorial identity (of self being an engaged resident of a specific place, having the sense of hostmanship and ownership) and theme-related identity (of self being stakeholder in a specific project, i.e. playground, city lighting in a particular neighbourhood, or bike path, etc.) To stimulate citizen involvement in the PB, the policymakers can appeal to citizens through three types of identity: active citizen identity ("good citizens participate" message), territorial identity ("this is your city" message), themerelated ("you have the power to fix your problem" message).

From the international perspective, local variants allow for the organisation of PB either at the city level or at the level of a single district within a city. The process should be repetitive and should encompass deliberation via specific forums or meetings. Accountability is considered as an indispensable part of PB to guarantee feedback with regards to the results of the process. Sintomer et al. also observe that according to these criteria, there were up to 1470 PBs in 2010 alone. Stortone 
stresses that there is no single universal model of PB. The approaches differ depending on the local context. The impetus for the participatory process can sprout from the grassroots groups or from the local authorities. The proportion of the local budget being subject to decision-making can be substantial or minor. The nature of the process can be more deliberative (co-deciding with citizens), or consultative (collecting information on citizens' needs, and cherry-picking those initiatives that are convenient for authorities). PB can be institutionalised and obligatory, or informal and build up according to political will. It can be an autonomous expression of social preferences, when self-ruled by civil society, or leave space for the representation of the government in deliberation. The emergent differences concern also the timeframe (cyclical vs. irregular), the type of participants (only individuals vs. various organisations inc. companies and interest groups), and the social coverage (all residents vs. specific social sectors/themes such as minorities, the elderly, women, etc.) (Stortone). Cabannes proposes the following typology of $\mathrm{PB}$ arrangements: minimal, medium and advanced, and differentiates them according to the following dimensions: (i) participatory (who is entitled to submit and select the projects in the $\mathrm{PB}$ process); (ii) financial, fiscal and budgetary (how much is spent on the PB projects in relationship to the size of the city budget); (iii) legal and normative (is $\mathrm{PB}$ framed into the local regulations concerning microallocation of resources); (iv) territorial (do $\mathrm{PB}$ projects and process cover the entire territory of the place). In contrast, Sintomer et. al discuss six ideal models of PB by analysis of political context; normative orientation; procedures; nature of the collective action; a link between conventional and participatory politics; as well as the strengths, weaknesses and challenges of the process. The participatory democracy model (Porto Alegre in Brazil) offers the best framework for the empowerment of all residents and the mobilization of civil society. The other examples of this model are Belo Horizonte (Brazil) and Chengdou (China). This model comprises a wide array of incentives for the citizens to participate: a legal framework for self-organising committees of neighbourhoods, the grassroots democratic process of the selection of neighbourhood representatives, the inclusive deliberation on the project proposals, and empowerment of the process by a local government commitment to implement the projects that were selected by the citizens. The proximity democracy model is a consultative type of $\mathrm{PB}$, with a limited deliberation and selective listening of citizens that results in cherry-picking of ideas. Many PBs in Central and Eastern Europe follow this path, which can lead to disillusionment and reduced attachment to the place. In the situation of scarce resources, some cities try to instrumentalise the $\mathrm{PB}$ procedures to promote the projects that should have their firm position in the regular local budgets such as infrastructure of primary and secondary education, or road safety (Lodz in Poland). The lack of deliberation reduces the potential of $\mathrm{PB}$ in the development of place attachment based on real-time interactions between the engaged residents. The participative modernisation model treats the PB 
as a tool of New Public Management with little interest in social justice. PB procedure in Cologne lies halfway between this model and the model of proximity democracy. Participation is here instrumentalised as a means to modernise the public administration. The multi-stakeholder participation model presents a donor-based perspective, where civil society is only one of many the players in the process (Plock in Poland). The neo-corporationism model shifts focus from civic society to an even greater extent in comparison to the previous model, to those "who matter," i.e. organised groups and local institutions. The role of individuals is marginal, and that is a barrier for the processes of the formation of identity. Token participation negatively influences citizens' involvement in contrast to the authentic participation, wherein citizens' input is valued and acted upon (Hafer and Ran). The experiments with PB in Albacete in Spain possessed some features of this approach, but it should be noted that this orientation is mainly present at a national and an international level (Sintomer et al.). Finally, the community development model is embedded in the normative frames of pedagogy of the oppressed. In the conditions of a mature community tradition and the high quality of deliberation, the members of upper, working and middle-class play the role of representatives of the socially excluded. Historically, the path-dependent features of the local social organising processes constitute a fundament of a particular PB model (Toronto, London). In comparison to participative democracy model, community development model emerges in the absence of strong local government.

When the representatives of the civil society and the local authorities share the aims of community improvement, an overlap in boundaries between community governance and public sector governance is created (Totikidis et al.). This constitutes an important insight for place managers. Community governance means that the local authorities think of the overall welfare of the place instead of narrow service orientation. They play a subsidiary role in communities, perform the enabler's task instead of controlling the contribution of non-state actors in local policies. Thus, they optimise the use of local resources for the benefit of the place, while paying attention to the needs of the community, and accepting a role of a leader, a reconciler, and - if necessary - a judge (Clarke and Stewart). When performing the three latter roles local authorities should remember about the diversity of perspectives, interests and issues that stem from the heterogeneity of places.

\section{Participatory budgeting - leverage for citizen identity and attachment to place?}

Both participatory democracy model and community development model have potential in building citizen identity and place attachment. The former induces place attachment by providing citizens with opportunities for meaningful impact on how 
their neighbourhoods function and for the delivery of tangible benefits. The latter constantly recreates the sense of ownership of place by positive reinforcement of the responsibility for a place and its residents among those who participate. As Allegretti poses, success factors of $\mathrm{PB}$ are: (i) political will, (ii) the organisational and the propositional capability of the social fabric, (iii) the financial autonomy of the institution proposing the $\mathrm{PB}$ and the resources available for the $\mathrm{PB}$, (iv) the organisation of the process and (v) the rules with which the $\mathrm{PB}$ warrants equal access for all potential participants. Advisory models of $\mathrm{PB}$ that result in selective listening might have a detrimental effect on place attachment in comparison to co-decision models that place the citizen in a central position. The adverse effect of the advisory models is the dispersion of social capital: a sense of disillusionment "when an individual understands that the good will with which he donated his free time and knowledge for a process of a supposed social transformation was underrated" (Allegretti 51). Avritzer claims that PB requires the commitment of both: a willing political class and robust civil society. Through $\mathrm{PB}$ civil society becomes a part of the new state and the so-called diagonal accountability emerges. PB is "a step beyond both the traditional watchdog or society-driven horizontal role of civil society as well as protest or referendum [...] Instead of trying to influence policy from the outside, the citizens [...] are invited inside the governmental apparatus itself” (World Bank 14, emphasis original; see fig. 2).

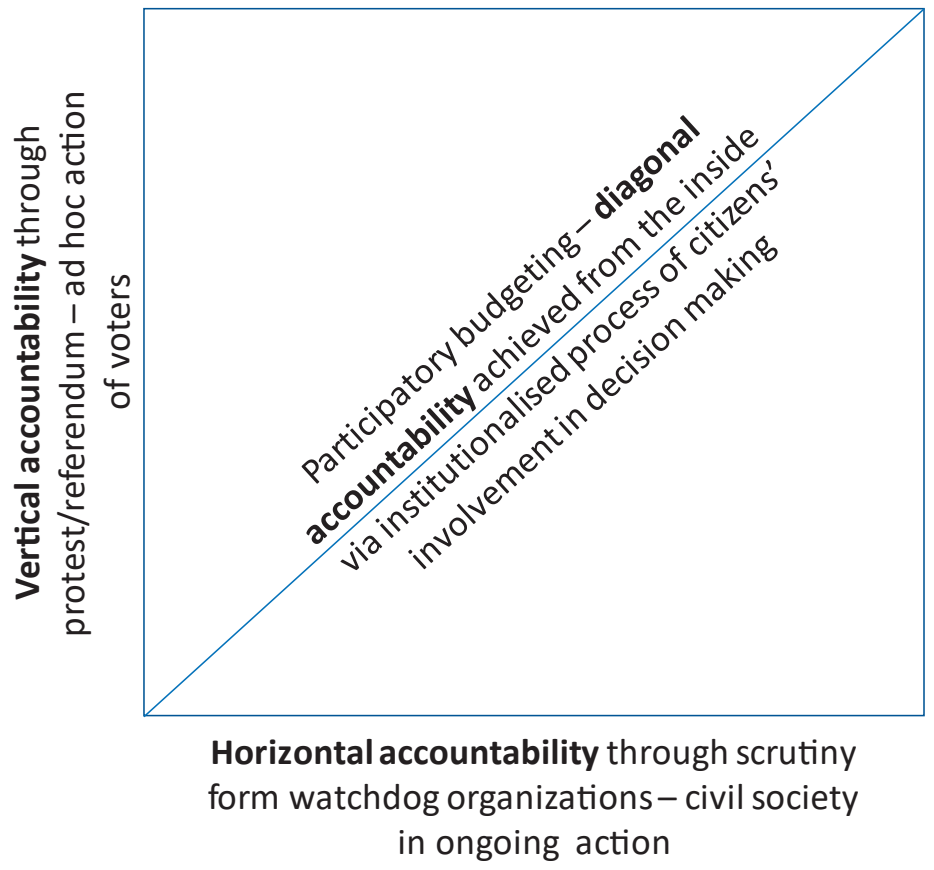

Figure 2. Placing civil society at the core of governance processes in Participatory Budgeting 
Following the previous discussion, we propose that further research on the subject should revolve around the mechanisms that lay behind citizens' motivation to participate in place-related initiatives with special attention being given to the influence of place attachment on the formation of social identity and vice versa. Considering the public policy perspective on the subject, an emerging issue is what methods and instruments can the place's authorities use to stimulate place attachment and authentic participation. To this end, various participatory budgeting models should be explored in order to assess its impact on the strengthening of the bond between places and its residents. The value of participatory budget as a concept for understanding of these problems resides in its potential to offer tangible benefits that are transferred from social exchange to the individual level (see fig. 3).

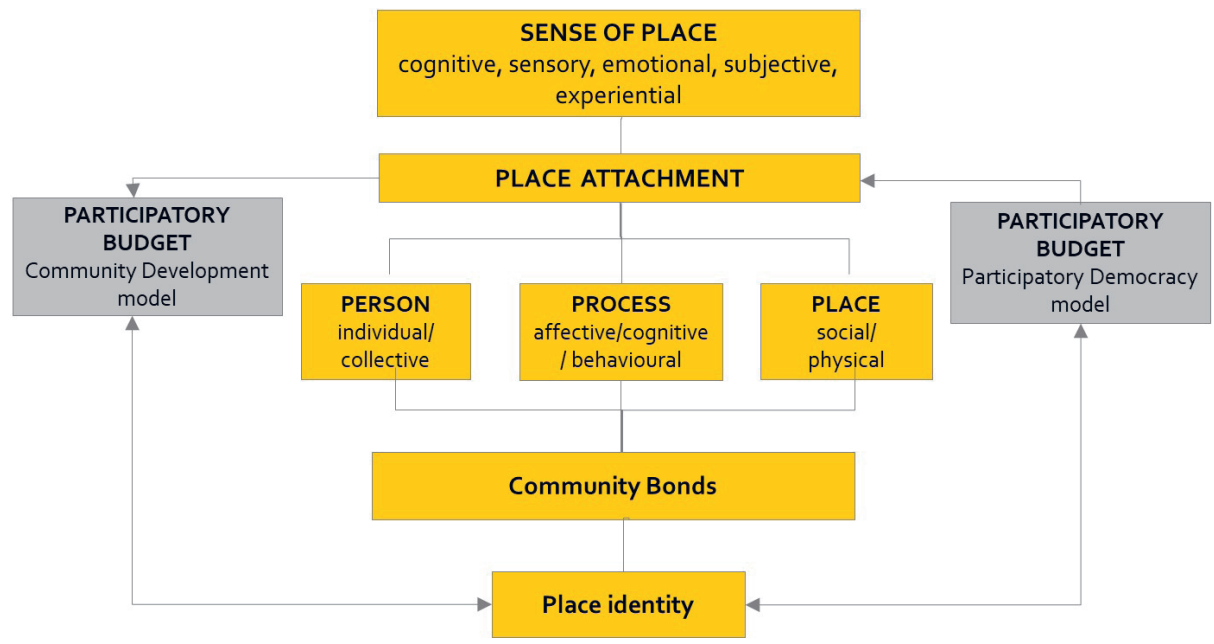

Figure 3. Participatory budget as an instrument for strengthening

Therefore, the authors propose that the following research propositions need to be considered:

P1. Place attachment can lead to the citizens' increased inclination to participate (in the case of the community development model of PB);

P2. Citizen participation can lead to a stronger place attachment (in the case of the participatory democracy model of $\mathrm{PB}$ );

$\mathrm{P}_{3}$. Participation may lead to stronger place identity through creation of social identity in three dimensions: citizen, territorial and theme-related.

Given the implications of the above research propositions for the practice of place management, it must be noted that urban planning policies should take into account the participatory budget approach as much as possible, to be able 
to reinforce place identity which can be treated dually. Firstly, as a factor stimulating social involvement and participation, and secondly, as a cohesive principle for the creation of territorial communities.

\section{Works Cited}

Allegretti, G. "Paying Attention to the Participants' Perceptions in Order to Trigger a Virtuous Circle." Hope for Democracy: 25 Years of Participatory Budgeting Worldwide. Ed. N. Dias. In Loco Association: São de Alportel, 2014.

Altman, I. , and S. M. Low, eds. Place Attachment. New York: Plenum, 1992.

Ashforth, B. E., et al. "Identification in Organizations: An Examination of Four Fundamental Questions.” Journal of Management 34.3 (2008): 325-374. http:// dx.doi.org/10.1177/0149206308316059

Avritzer, L. Participatory Institutions in Democratic Brazil. Washington D.C.: Woodrow Wilson Centre Press, 2009.

Baiocchi, G. Militants and Citizens: The Politics of Participatory Democracy in Porto Alegre. Stanford: Stanford University Press, 2005.

Baiocchi, G. "Participation, Activism, and Politics: The Porto Alegre Experiment and Deliberative Democratic Theory." Politics \& Society 29.1 (2001): 43-72. http:// dx.doi.org/10.1177\%2F0032329201029001003

Braun, B. B., et al. "Place Attachment in Revitalizing Neighbourhoods. Individual and Block Levels of Analysis.” Journal of Environmental Psychology 23 (2003): 259-271.

Cabannes, Y., Participatory Budgeting: Conceptual Framework and Analysis of Its Contribution to Urban Governance and the Millenium Development Goals. Working Paper 140, Quito: UN Habitat, 2004, pp. 1-65.

Campelo, A. "Rethinking Sense of Place. Sense of One and Sense of Many." Rethinking Place Branding: Comprehensive Brand Development for Cities and Regions. Eds. M. Kavaratzis, et al. Springer, Cham, 2015, pp. 51-60.

Clarke, M., and J. Stewart. Community Governance, Community Leadership and the New Local Government. York: York Publishing Services, 1998.

Cross, J. E. What is Sense of Place?, paper prepared for the 12th Headwaters Conference, Western State College, 2-4 Nov 2001.

De Sousa Santos, Boaventura. "Participatory Budgeting in Porto Alegre: Toward a Redistributive Democracy.” Politics \& Society 26.4 (1998): 461-510. http://dx.doi. org/10.1177\%2F0032329298026004003

De Souza Santos, Boaventura, ed. Democratizing Democracy: Beyond the Liberal Democratic Canon. London: Verso, 2007.

Fuhr, H., and T. Campbell. Leadership and Innovation in Subnational Government: Case Studies from Latin America, World Bank Development Studies, Mar 2004. http://dx.doi.org/10.1596/0-8213-5707-7 
Fung, A. Empowered Participation: Reinventing Urban Democracy, Princeton: Princeton University Press, 2009.

Gieseking, Jen Jack, et al., eds. The People, Place, and Space Reader. New York and London: Routledge, 2014.

Habermas, J. Between Facts and Norms, Cambridge, MA: MIT Press, 1996.

Hafer, J. A. and B. Ran. "Developing a Citizen Perspective of Public Participation: Identity Construction as Citizen Motivation to Participate." Administrative Theory \& Praxis 38 (2016): 206-222.

Hague, L. A. "Identity and Place: a Critical Comparison of Three Identity Theories." Architectural Science Review 50.1 (2007): 44-51.

Harvard University Centre for Urban Development Studies. Assessment of Participatory Budgeting in Brazil, Washington: Inter-American Development Bank, 2003, p. 10.

Ingram, H., and S. R. Smith. Public Policy for Democracy. Washington, D.C.: Brookings Institution Press, 2011.

Jorgensen, Bradley S., and Richard C. Stedman. "Sense of Place as an Attitude: Lakeshore Owners Attitudes toward Their Properties." Journal of Environmental Psychology 21.3 (2001): 233-248.

Kavaratzis, Mihalis, and Mary Jo Hatch. "The Dynamics of Place Brands: An Identitybased Approach to Place Branding Theory." Marketing Theory 13.1 (2013): 69-86. Kerr, Greg, and Jessica Oliver. "Rethinking Place Identities." Rethinking Place Branding Comprehensive Brand Development for Cities and Regions. Ed. M. Kavaratzis, et al. Springer, Cham, 2015, pp. 61-72.

Low, S. On the Plaza: The Politics of Public Space and Culture. Austin: University of Texas Press, 2000.

Low, Setha M., and Irwin Altman. "Place Attachment: A Conceptual Inquiry." Place Attachment. Ed. I. Altman and S. Low. Boston, MA: 1992, pp. 1-12.

Lowndes, V., et al. "Diagnosing and Remedying the Failings of Official Participation Schemes: The CLEAR Framework." Social Policy and Society 5.2 (2006): 281-291. http://dx.doi.org/10.1017/s1474746405002988

Manzo, L. C. "Beyond House and Haven: Toward a Revisioning of Emotional Relationships with Places." Journal of Environmental Psychology 23.1 (2003): 47-61.

Marquetti, A., et al. "Participatory Economic Democracy in Action." Review of Radical Political Economics 44.1 (2011): 62-81. http://dx.doi. org/10.1177\%2F0486613411418055

Maton, K. I. "Empowering Community Settings: Agents of Individual Development, Community Betterment, and Positive Social Change." American Journal of Community Psychology 41.1-2 (Mar 2008): 4-21. https://doi.org/10.1007/ s10464-007-9148-6 
Peters, B. G., and J. Pierre. "Citizens versus the New Public Manager: The Problem of Mutual Empowerment.” Administration and Society 32.1 (2000): 9-28. https://doi. org/10.1177/00953990022019335

Proshansky, H. M. et al. "Place-Identity: Physical World Socialization of the Self." Journal of Environmental Psychology 3 (1983): 57-83.

Relph, E. Place and Placelessness. London: Pion, 1976.

Roberts, N. "Public Deliberation in an Age of Direct Citizen Participation." American Review of Public Administration 34.4 (2004): 315-353. http://dx.doi. org/10.1177/0275074004269288

Scannell, L., and R. Gifford. "Defining Place Attachment. A Tripartite Organization Framework." Journal of Environmental Psychology 30 (2010): 1-10.

Silva, Marcelo Kunrath. "Participation by Design: The Experiences of Alvorada and Gravataí, Rio Grande do Sul, Brazil.” Radicals in Power The Workers' Party (PT) and the Experiments in Urban Democracy in Brazil. Ed. Gianpaolo Biaocchi. London: Zed Books 2003, pp. 113-130.

Simmons, R., and J. Birchall. "A Joined-up Approach to User Participation in Public Services: Strengthening the 'Participation Chain." Social Policy \& Administration 39 (2005): 260-283. http://dx.doi.org/10.1111/j.1467-9515.2005.00439.x

Sintomer, Y., et al. "Transnational Models of Citizen Participation: The Case of Participatory Budgeting." Journal of Public Deliberation 8.2 (2012).

Stortone, S., "Participatory Budgeting: Heading Towards a 'Civil' Democracy?" A Panacea for All Seasons? Civil Society and Governance in Europe. Eds. M. Freise, et al. Baden-Baden: Nomos, 2010, pp. 99-119

Tajfel, H. Social Identity and Intergroup Relations. Cambridge: Cambridge University Press, 1982.

Totikidis V., et al. “The Concept of Community Governance: A Preliminary Review.” Refereed paper presented at the GovNet Conference, Monash University, Melbourne, 28-30th November, 2005. http://vuir.vu.edu.au/955/1/The_Concept_ of_Community_Governance.pdf (Accessed 29 Mar 2017)

Vigoda, E. "From Responsiveness to Collaboration: Governance, Citizens, and the Next Generation of Public Administration." Public Administration Review 62 (2002): 527-540. http://dx.doi.org/10.1111/1540-6210.00235

Wampler, Brian. Participatory Budgeting in Brazil: Contestation, Cooperation, and Accountability. University Park: Penn State Press, 2010.

Wampler, Brian. "Participatory Budgeting: Core Principles and Key Impacts". Journal of Public Deliberation 8.2. (2012): 12-1 -12-13.

World Bank. State Society Synergy for Accountability. Lessons for the World Bank. World Bank Working Paper No 30. Washington D.C.: The World Bank, 2004. 
Justyna Anders-Morawska - Assistant Professor at the University of Lodz, Faculty of International and Political Studies. In her academic work, she concentrates on the issues of inter-organisational relations in urban policy. Her recent research focus covers problems of creative placemaking, the role of arts and artists in urban development, and participatory art practices from the perspective of cultural policy. She has co-authored the first Polish monograph that applies market orientation concept in the operationalisation of metropolitan governance processes. She is a member of the programme board in the study group Administration and Public Policies (Polish Association of Political Science), a member of Scientific Council at Interdisciplinary Centre of Urban Studies of the University of Lodz and a classically trained pianist.

Marta Hereźniak - Assistant Professor at the University of Lodz, Poland. The author of the first Polish doctoral dissertation and the first book about nation-branding, she has authored and co-authored academic and popular publications on placebranding and brand management. She is a member of the International Place Branding Association and the Institute of Place Management, a full-time teacher at the International Marketing programme (taught in English; Bachelor and Master's courses); an expert of the Polish Chamber of Commerce and the Institute of Polish Brand, and a consultant in brand-related projects for companies, public institutions and local governments. She is also a member of the Brand-for-Poland project chaired by Wally Olins; a leading consultant in the project on Kazakhstan country brand and a co-author of the European Funds Brand strategy in Poland. Her research interests include place brand identity development; measurement of place branding effectiveness, stakeholder engagement in place branding, and place of origin branding. 